How to Cite: Malyshev, V.P., Makasheva, A.M., Bekbayeva, L.A. (2021) Invariants of ratio of crystal-mobile, liquid-mobile, and vaporized chaotized particles in solid, liquid, and gas states of substance. Bulletin of the University of Karaganda - Chemistry, 104(4), 69-78. https://doi.org/10.31489/2021Ch4/69-78

\author{
V.P. Malyshev ${ }^{1}$, A.M. Makasheva ${ }^{2 *}$, L.A. Bekbayeva ${ }^{2}$ \\ ${ }^{1}$ Abishev Chemical-Metallurgical Institute, Karaganda, Kazakhstan; \\ ${ }^{2}$ Karaganda Technical University, Karaganda, Kazakhstan \\ (*Corresponding author's e-mail: astra_mun@mail.ru)

\section{Invariants of ratio of crystal-mobile, liquid-mobile, and vaporized chaotized particles in solid, liquid, and gas states of substance}

\begin{abstract}
The authors of the article have developed the concept of chaotic particles based on the Boltzmann distribution over the kinetic energy of the particles' chaotic motion. This distribution allows to combine the solid, liquid, and gaseous states of matter with the help of energetic particles called crystal-mobile, liquid-mobile, and vapor-mobile. The ratio of the proportions of such randomized particles determines a certain state of matter aggregation. The sum of the shares of these particles in all combinations at any temperature is equal to unity. During the study it has identified that qualitative and quantitative analysis of states with a priority basic effect of a randomized component of a substance can be conducted. Certain regularities of states were discovered, independent of the specific type of substance and consistent with the physicochemical properties. The entropy of mixing of all three energy classes of chaotic particles was calculated for simple substances. It was characterized by a maximum in the interval of the boiling point of substances. This feature testifies to the unique variety of possibilities for the implementation of the most complex heterogeneous processes in terrestrial conditions at atmospheric pressure, which ultimately ensured the self-organization of life.
\end{abstract}

Keywords: Boltzmann distribution, kinetic energy, chaotic particles, entropy, zero approximation, barium, melting point, boiling point.

\title{
Introduction
}

Until now, there is no sufficiently complete theory of the liquid state of matter, if only because, in contrast to the gaseous and solid states, there is no "zero approximation" for the intermediate state [1]. So, there is no attraction or electronic repulsion of particles in an ideal gas, that is, the potential energy of their interaction is neglected. In an ideal crystal, there are no violations in the correctness of the crystal lattice due to neglect of the kinetic (thermal) energy of the chaotic motion of particles. If we understand the ideal liquid state of matter as an intermediate one in terms of these neglections, then we get an absurd paradox: in an ideal liquid, both potential and kinetic energy should be neglected.

Such a result is a consequence of a logical error, which is known in philosophy in the form of a statement: any definition through negation is flawed. One should focus on the preservation of any feature or property, and not on its absence. In this case, thermal energy turns out to be a single primordial property of matter in all its states of aggregation, which should be taken as a zero approximation for the state of matter as a whole, avoiding opposing one state of aggregation to another, which leads more to paradoxes than to understanding the essence of the matter.

The proposed zero approximation turns out to be constructive because there is a universal tool for its use - the fundamental distribution, or energy spectrum of Boltzmann, which is also applicable to separately taking into account the effect of kinetic energy on a given distribution not only for gaseous, but also for concentrated states [2]. In this case, it is sufficient to know the melting points $T_{m}$ and boiling points $T_{b}$ of the substance in order to distinguish the energy classes of random particles located above or below these barriers from the thermal barriers of melting $R T_{m}$ and boiling $R T_{b}$, and to judge their character of influence on the solid, liquid, and gaseous states in the corresponding temperature intervals; $0-T_{m}, T_{m}-T_{b}, T_{b}-\infty$.

The concept of chaotic particles put forward by the authors is based on this idea [3], which allows using the Boltzmann distribution ( $E_{i}$ is the kinetic energy):

$$
P_{i}=e^{-\frac{E_{i}}{R T}} / \sum_{i=1}^{\infty} e^{-\frac{E_{i}}{R T}}
$$

to determine the share of low-energy particles called crystal-mobile: 


$$
P_{c r m}=1-\exp \left(-\frac{R T_{m}}{R T}\right)=1-\exp \left(-\frac{T_{m}}{T}\right),
$$

the share of medium-energy particles called liquid-mobile:

$$
P_{l q m}=\exp \left(-\frac{T_{m}}{T}\right)-\exp \left(-\frac{T_{b}}{T}\right),
$$

and the share of high-energy particles called vapor-mobile:

subject to the condition

$$
P_{v m}=\exp \left(-\frac{T_{b}}{T}\right)
$$

$$
P_{c r m}+P_{l q m}+P_{v m}=1 .
$$

This mathematical model is the "zero approximation" of all three aggregate states individually and as a whole, since their shares are compatible at any temperature.

The purpose of this work is to qualitatively and quantitatively estimate the entropy invariants of mixing of randomized particles using the Boltzmann distribution for simple substances.

\section{Experimental}

In this model, invariants of the $P_{c r m}, P_{l q m}, P_{v m}$ ratios are immediately revealed under boundary temperature conditions. So, at $T=0$, the share of crystal-mobile particles is equal to unity and, accordingly, the shares of liquid and vapor-mobile particles are zero. This characterizes the solid state of matter in the form of an ideal crystal. At $T=\infty$, only vapor-mobile particles exist and the state of matter corresponds to the concept of an ideal gas. At the melting point, $P_{c r m}=0.632$, and the sum $P_{l q m}+P_{v m}=0.368$. If we assume that crystal-mobile particles provide the stability of the solid state of matter, and liquid and vapor-mobile ones violate this stability, then the ratio 0.632:0.368 should be understood as the limiting invariant of the preservation of the solid state, related to the system-wide characteristics of stability. The golden ratio of 0.618:0.382 is the closest to this ratio, which serves as a universal measure of the structural harmony of the system, their structural and chaotic sides in the widest class of objects [4, 5].

The same applies to the boiling point, with the difference that there is a transition from a condensed state to a vapor state and the sum of the crystal-mobile and liquid-mobile particles is the binding component, and the content of the vapor-mobile particles is chaotic. This follows from the fact that at $T=T_{b} P_{v m}=0.368$, and $P_{c r m}+P_{l q m}=0.632$.

Knowledge of the specific values of $T_{m}$ and $T_{b}$ is required for a more detailed analysis of the $P_{c r m}: P_{l q m}: P_{v m}$ ratio at any temperature, although in the most general form, it is possible to establish its own invariants for each state.

So, in the interval $0 \div T_{m}$, the share of crystal-mobile particles changes from unity to $P_{c r m}=0.632$, and function (2) undergoes an inflection, further tending to zero at $T \rightarrow \infty$. This inflection is detected by double differentiation (2)

$$
\frac{\partial^{2} P_{c r m}}{\partial T^{2}}=\frac{T_{m}}{T^{3}}\left(2-\frac{T_{m}}{T}\right) \exp \left(-\frac{T_{m}}{T}\right),
$$

from which, when equating to zero, in addition to the asymptotic approximation of function (2) to unity at $T \rightarrow 0$ and to zero $T \rightarrow \infty$, the position of the inflection point of this function is established at $T=0.5 T_{m}$. At this point, there is a maximum decrease in crystal-mobile particles and, accordingly, an increase in the sum of liquid- and vapor-mobile particles. In this case, the crystal retains high connectivity $P_{c r m}=0.865$, but turns out to be noticeably loosened $P_{l q m}+P_{v m}=0.135$ and thus prone to plastic deformation and melting.

This is consistent with the well-known Bochvar-Tamman temperature, which refers to the optimal temperature of plastic deformation $T_{\text {opt }} \approx 0.5 T_{m}$ and is either experimentally recorded or generalized on the basis of a large number of experimental data [6]. At this temperature, diffusion in the lattice of the solid becomes noticeable and its reactivity begins to manifest itself.

There are also more subtle features of the temperature dependence of the properties of a solid. According to Tamman, the mobility of particles on the crystal surface is found to be about $0.3 T_{m}$. It has been also found that at temperatures above $0.5 T_{m}$ deformation is not accompanied by hardening and the metal flows at a constant rate under a constant load, which is characterized as its creep. This is explained by the increased role of vacancies, and the number of atoms in the inter-aisles, and indeed the entire set of defects in the crys- 
tal. The movement of defects occurs due to thermal fluctuations, the frequency of which always decreases with decreasing temperature. It is noted that the region $(0.4 \div 0.8) T_{m}$ is the most typical for creep $[6,7]$.

Thus, in addition to the optimal plasticity temperature $0.5 T_{m}$, the zone of manifestation of plasticity effects $(0.3 \div 0.8) T_{m}$ is also the empirical invariants of plasticity. In this case, the beginning of this zone can be interpreted as an area of acceleration of these effects manifestation, and the end of the zone - as an area of slowing down of this process. However, as applied to the temperature dependence of the share of crystalmobile particles (2), Eq. (6) takes on the meaning of the rate of decrease in the content of these particles. This will allow it to be used to express acceleration by taking the third derivative

$$
\frac{\partial^{3} P_{c r m}}{\partial T^{3}}=T_{m} T^{-4}\left(-6+6 T_{m} T^{-1} T_{m}{ }^{2} T^{-2}\right) \exp \left(-\frac{T_{m}}{T}\right),
$$

in which, the asymptotic tendency of acceleration to zero at $T=0$ and $T=\infty$, equating the trinomial to zero leads to the quadratic equation

$$
6 T^{2}-6 T_{m} T+T_{m}^{2}=0
$$

having two real roots

$$
T_{1,2}=\frac{T_{m}(3 \pm \sqrt{3})}{6} .
$$

From this, within the framework of the chaotic particles concept, two extreme invariant points are found, namely the maximum acceleration of the decrease in the share of crystal-mobile particles,

$$
T_{1}=\left(0.5-\frac{\sqrt{3}}{6}\right) T_{m} \approx 0.21 T_{m},
$$

and the minimum acceleration of the loss of these particles,

$$
T_{2}=\left(0.5+\frac{\sqrt{3}}{6}\right) T_{m} \approx 0.79 T_{m},
$$

which correlate with the experimentally found plasticity zone $(0.3 \div 0.8) T_{m}$.

The obtained results allowed the authors to express for the first time the useful energy costs for plastic deformation at any temperature in the form of an addition to the thermal energy at the melting point

$$
\Delta E=R T_{m}-R T=R\left(T_{m}-T\right)
$$

and determine the energy efficiency of rolling mills [7].

The temperature dependence of the share of vapor-mobile particles (4) mathematically corresponds to the inverse mapping of dependence (2) for crystal-mobile particles, with the difference that the temperature is normalized according to $T_{b}$. Nevertheless during differentiation, the form of the derivatives differs only in sign (the function increases instead of decreasing) while maintaining the same form of the invariants: inflection points at $0.5 T_{b}, T_{1}=(0.5-\sqrt{3} / 6) T_{b} \approx 0.21 T_{b}, T_{2}=(0.5+\sqrt{3} / 6) \approx 0.79 T_{b}$. However, if the range of invariants of crystal-mobile particles refers to the solid state, then a similar range for the gaseous state as a whole enters the condensed state with a possible strike even in a solid in dependence on the specific ratio of $T_{b}$ and $T_{m}$ for each substance.

It can be expected that the revealed features for the behavior of vapor-mobile particles directly relate to the temperature dependences of vapor in equilibrium with a solid and a liquid, as well as to some subtle effects of the presence of vapor-mobile particles in the condensed bodies themselves, since the invariant at $T_{1}$, $0.5 T_{b}$ and $T_{2}$ correspond small fractional values $P_{v m}$ equal to: $0.086 ; 0.135$ and 0.282 , against those set for crystal-mobile particles: $0.992 ; 0.865$ and 0.718 .

The mathematical model for liquid-mobile particles (3) is determined by the influence of both the melting and boiling points, and therefore, taking into account the opposite nature of the corresponding temperature dependences for crystal-mobile and vapor-mobile particles, it should contain a maximum. It can be found analytically by differentiating function (3) and equating the derivative to zero:

$$
\frac{d P_{l q m}}{d T}=\frac{1}{T^{2}}\left[T_{m} \exp \left(-T_{m} / T\right)-T_{b} \exp \left(-T_{b} / T\right)\right]=0,
$$

whence we found, in addition to the horizontal asymptotes at $T=0$ and $T=\infty$, also the maximum point $P_{\text {lqm }}$

$$
T_{\max , l q m}=\frac{T_{b}-T_{m}}{\ln \left(T_{b} / T_{m}\right)},
$$


Substituting (14) into (3), we determine the maximum share of liquid-mobile particles

$$
P_{l q m, \max }=\exp \left[-\frac{T_{m} \ln \left(\frac{T_{b}}{T_{m}}\right)}{T_{b}-T_{m}}\right]-\exp \left[\frac{T_{b} \ln \left(\frac{T_{b}}{T_{m}}\right)}{T_{b}-T_{m}}\right] .
$$

For any ratio of $T_{m}$ and $T_{b}$, this invariant of liquid-mobile particles is entirely in a liquid state, and this can be proved by limiting oneself to the natural conditions $T_{b}>T_{m}$ and, accordingly, $\frac{T_{b}}{T_{m}}>1$.

To this end, we first prove the inequality $T_{\max , \text { lqm }}>T_{m}$ :

$$
\frac{T_{b}-T_{m}}{\ln \left(T_{b} / T_{m}\right)}>T_{m}
$$

By means of identical transformations (15), we arrive at the expression

$$
\frac{T_{b}}{T_{m}}>1+\ln \frac{T_{b}}{T_{m}},
$$

from which it follows that since $\ln \frac{T_{b}}{T_{m}}>0$, then $\left(1+\ln \frac{T_{b}}{T_{m}}\right)>1$ and then $T_{b}>T_{m}$ in accordance with the initial conditions.

To prove that $T_{\max , q m}<T_{b}$,

$$
\frac{T_{b}-T_{m}}{\ln \left(T / T_{m}\right)}<T_{b},
$$

by similar identical transformations (17) is reduced to the inequality

$$
\frac{T_{m}}{T_{b}}-\ln \frac{T_{m}}{T_{b}}>1
$$

Taking into account that for the region $0<\frac{T_{m}}{T_{b}}<1$ the inequalities $\frac{T_{m}}{T_{b}}>\ln \frac{T_{m}}{T_{b}}$ and $\frac{T_{m}}{T_{b}}<\left|\ln \frac{T_{m}}{T_{b}}\right|$, the validity of inequality (18) follows, which is confirmed by its numerical analysis.

Belonging to the extreme content of liquid-mobile particles indicates its particular complexity, which, together with the present crystal-mobile and vapor-mobile particles in the same area, gives rise to widespread ideas about its mechanical mixture of solid and gaseous states [1]. However, the discussed extremality (14) does not at all refer to the equality of the shares of crystal-mobile and vapor-mobile particles, but to the algebraic equality of their increments.

\section{Results and Discussion}

All the noted features can be illustrated more clearly by the example of the relationship of aggregate states for barium - a typical metal of the second group of the Periodic Table of Chemical Elements (Fig. 1).

Figure 1 illustrates that the equality of the shares of $\mathrm{crm}$ - and $\mathrm{vm}$ - particles falls almost strictly at the boiling point. If we set it into the equation of equality of the shares of crystal-mobile (2) and vapor-mobile particles (4),

$$
1-\exp \left(-\frac{T_{m}}{T_{b}}\right)=\exp \left(-\frac{T_{b}}{T_{b}}\right),
$$

then we get the solution

$$
\frac{T_{m}}{T_{b}}=-\ln \left(1-e^{-1}\right) \cong 0.46
$$

whence follows

$$
T_{m} \cong 0.46 T_{b} .
$$




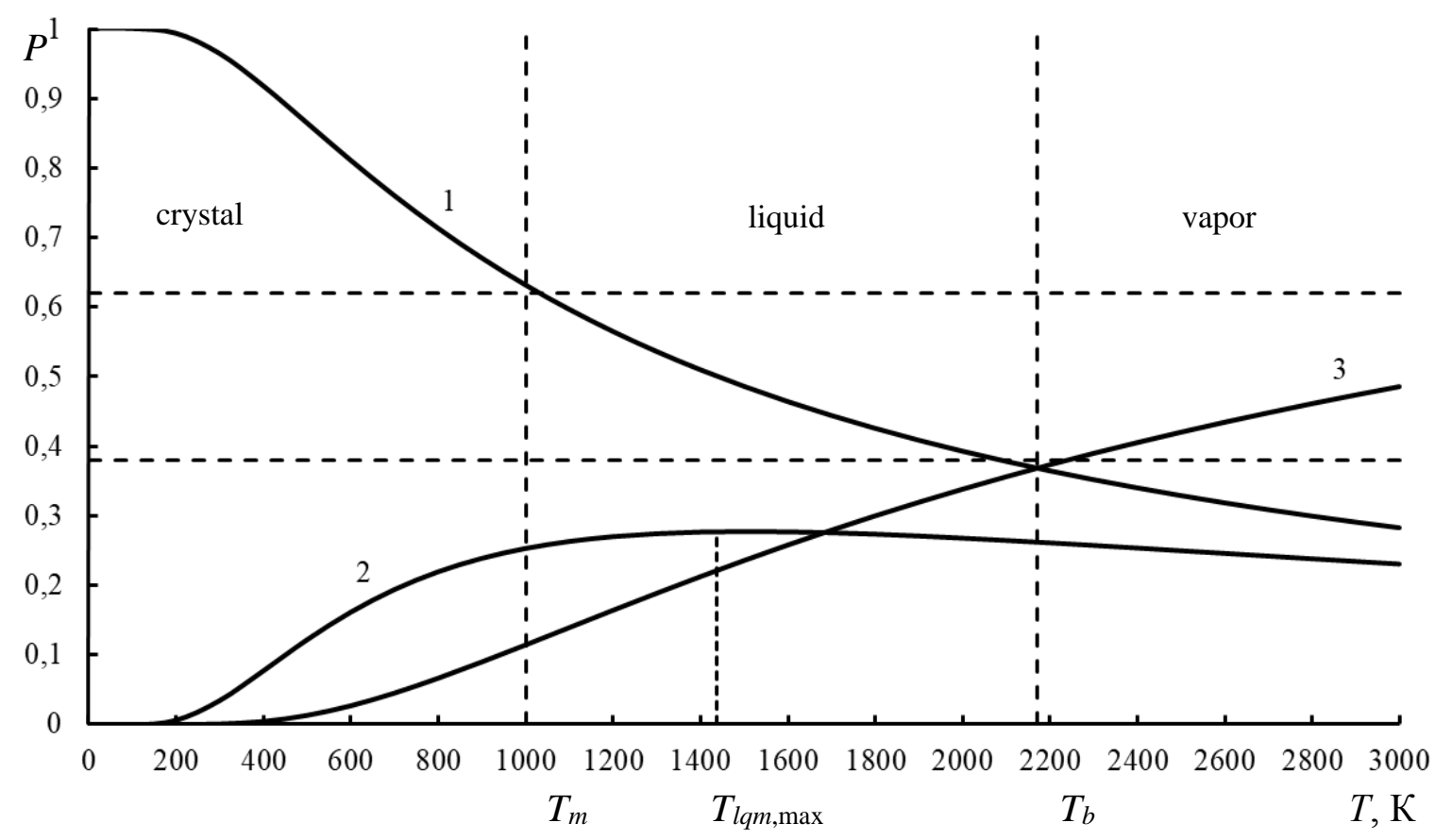

Vertical lines - by melting point $T_{m}$ and boiling point $T_{b}$,

horizontal lines - according to the proportion of the golden ratio $(\sim 0.62$ and $\sim 0.38)$.

Highlighted the temperature of the maximum of the share of liquid-mobile particles

Figure 1. Dependence of the shares of crystal-mobile (1), liquid-mobile (2), and vapor-mobile (3) particles on temperature for barium

This value is consistent with the average value of the $T_{b} / T_{m}$ ratio, established for 55 metals and equal to 2.2 [7], from which $T_{m} \cong 0,44 T_{b}$ has been found. This indicates a certain regularity in referring the equality of the shares of $\mathrm{crm}$ - and $\mathrm{vm}$ - particles to the boiling point.

The equality of shares, and hence the probability of detecting any signs of distinguishability of any objects, has a deeper meaning, which is associated with the achievement of the maximum uncertainty, or the system entropy [8-10,5]. From this point of view, attention is drawn to the proximity of the shares of $\mathrm{crm}$, lqm- and $\mathrm{vm}$ - particles referred to the boiling point. In this case, according to (2)-(5) at $T=T_{b}$, the ratio $P_{c r m}: P_{l q m}: P_{v m}=0.37: 0.37: 0.26$ is obtained. Full equality of the shares of these particles can be achieved by the condition $P_{c r m}=P_{l q m}=P_{v m}=1 / 3$, which allows us to find the necessary invariant relation by (4)

$$
\frac{1}{3}=\exp \left(-T_{b} / T\right) \text {. }
$$

In this ideal case, the temperature of the substance should be equal to $T=\left(T_{b} / \ln 3\right) \cong 0.91 T_{b}$, which confirms its proximity to the boiling point.

The required $T_{b} / T_{m}$ ratio (22) under real conditions can be observed only under suitable conditions, since the boiling point strongly depends on the external pressure, which is $101325 \mathrm{~Pa}$ on the Earth's surface and taken as normal conditions. The melting point depends on the external pressure to a much lesser extent, and therefore, the $T_{b} / T_{m}$ ratio can vary over a wide range, both natural and artificial.

The ratio of the shares of crystal-mobile, liquid-mobile, and vapor-mobile particles at any temperature can be expressed generally in the form of the entropy of mixing of these particles in accordance with their virtual existence and interconversion

$$
S_{m i x}=-R \sum_{1}^{n} p_{i} \ln p_{i},
$$

where $p_{i}$ is the proportion of different elements of the system to be mixed, $n$ is their number, $R$ is the universal gas constant equal to $8.314472 \mathrm{~J} / \mathrm{mol}$, when the process is expressed in terms of physical entropy. It can be presented in the form of

$$
S_{m i x}=-R\left(P_{c r m} \ln P_{c r m}+P_{l q m} \ln P_{l q m}+P_{v m} \ln P_{v m}\right),
$$


or in more detail, taking into account (2)-(5) as

$$
S_{m i x}=-R\left\{\begin{array}{c}
{\left[1-\exp \left(-\frac{T_{m}}{T}\right)\right] \ln \left[1-\exp \left(-\frac{T_{m}}{T}\right)\right]+\left[\exp \left(-\frac{T_{m}}{T}\right)-\exp \left(-\frac{T_{b}}{T}\right)\right] \times} \\
\times \ln \left[\exp \left(-\frac{T_{m}}{T}\right)-\exp \left(-\frac{T_{b}}{T}\right)\right]-\left(\frac{T_{b}}{T}\right) \exp \left(-\frac{T_{b}}{T}\right)
\end{array}\right\} .
$$

It is enough to differentiate (25) and equate the derivative to zero to find the temperature, at which the maximum entropy is realized. It seems impossible to analytically determine the position of this maximum due to the difficulty of freeing the temperature from the resulting transcendental equations; therefore, this temperature $T_{\text {Smax }}$ was determined numerically for all metals, for which reference data are available [11].

In general, the formation of the function maximum (24) is necessary, since these functions take zero values both at $T=0$ and at $T \rightarrow \infty$ due to the presence of only one kind of particles at this value, respectively $P_{c r m}=1$ and $P_{v m}=1$, due to which all fragments of equation (24) are zeroed both by the condition $1 \ln 1=0$ and by the condition $0 \ln 0=0 \cdot(-\infty) \cdot 0$.

The results of calculating the entropy of mixing of three energy classes of chaotic particles are shown by the example of barium in Table 1 and Figure 2 .

T a b l e 1

Entropy of mixing of $\mathrm{crm}$-, lqm- and $v m$-particles depending on temperature for barium

\begin{tabular}{|c|c||c|c||c|c||c|c|}
\hline$T, \mathrm{~K}$ & $S_{m i x}, \mathrm{~J} / \mathrm{mol}$ & $T, \mathrm{~K}$ & $S_{m i x}, \mathrm{~J} / \mathrm{mol}$ & $T, \mathrm{~K}$ & $S_{m i x}, \mathrm{~J} / \mathrm{mol}$ & $T, \mathrm{~K}$ & $S_{m i x}, \mathrm{~J} / \mathrm{mol}$ \\
\hline 0 & 0 & 800 & 6.270 & 1600 & 8.824 & 2300 & 9.016 \\
\hline 100 & $4.2 \cdot 10^{-3}$ & 900 & 6.871 & 1700 & 8.912 & 2400 & 8.989 \\
\hline 200 & 0.387 & $T_{m}=1000$ & 7.364 & 1800 & 8.974 & 2500 & 8.954 \\
\hline 300 & 1.309 & 1100 & 7.764 & 1900 & 9.014 & 2600 & 8.914 \\
\hline 400 & 2.503 & 1200 & 8.086 & 2000 & 9.036 & 2700 & 8.867 \\
\hline 500 & 3.650 & 1300 & 8.344 & 2100 & 9.041 & 2800 & 8.816 \\
\hline 600 & 4.672 & 1400 & 8.547 & $T_{b}=2170$ & 9.038 & 2900 & 8.762 \\
\hline 700 & 5.542 & 1500 & 8.704 & 2200 & 9.034 & 3000 & 8.705 \\
\hline
\end{tabular}

$S_{m i x}, \mathrm{~J} / \mathrm{mol}$

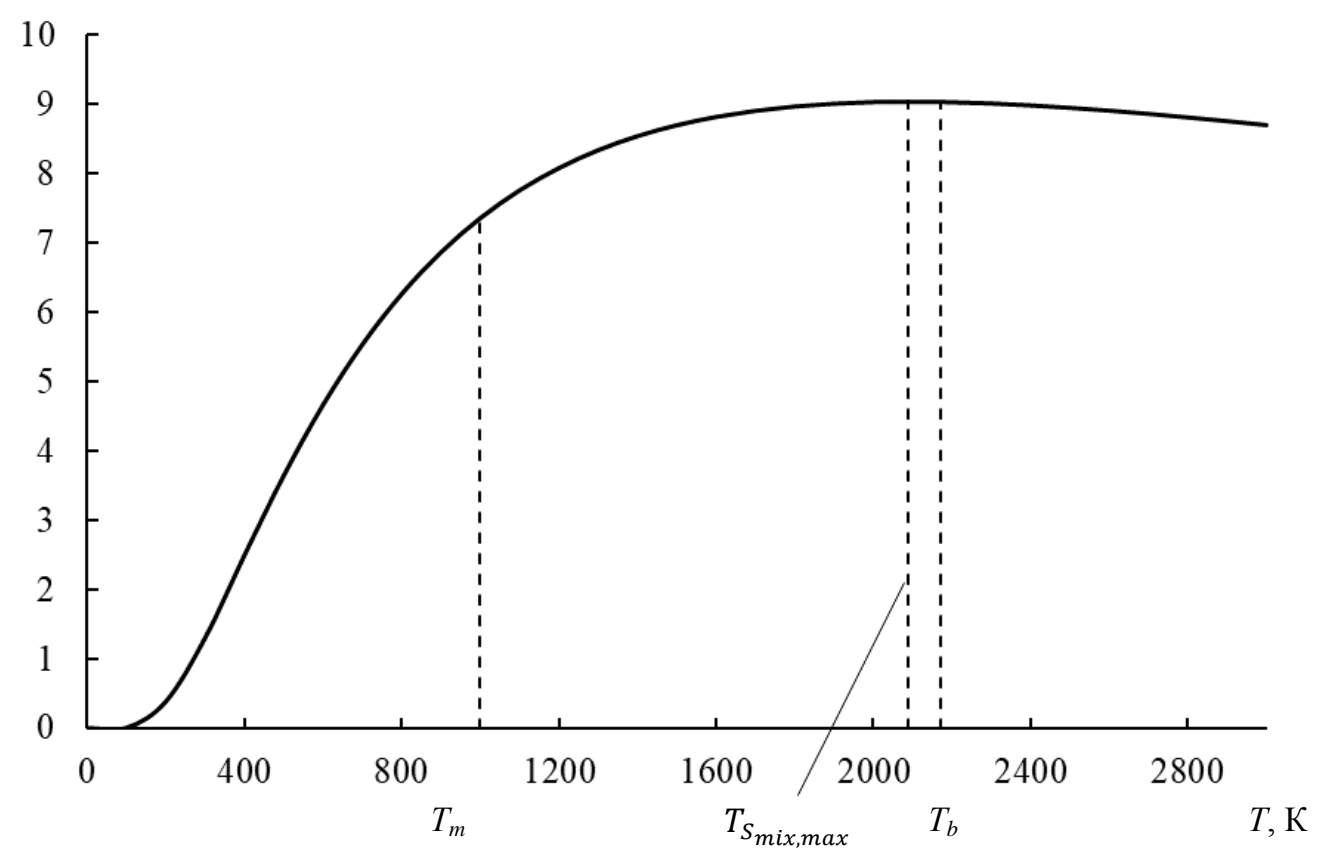

Figure 2. Dependence of the entropy of mixing of three energy classes of randomized particles on the barium temperature. Melting points, boiling points, and maximum entropy of mixing are indicated 
As can be seen from these data, the region of the maximum entropy of mixing is expressed rather smoothly, adjacent directly to the boiling point of barium with a value of $9.041 \mathrm{~J} / \mathrm{mol}$ at a temperature of $2090 \mathrm{~K}$, which is $0.963 T_{b}$. In this case, the difference between the values of the entropy of mixing themselves is even smaller: at $T_{b} S_{m i x}=9.038 \mathrm{~J} / \mathrm{mol}$, which ensures the ratio $\frac{S_{m i x, T_{b}}}{S_{m i x, m a x}}=0.99967$.

Similar results were obtained for 54 metals according to reference data for $T_{m}$ and $T_{b}$ [12], which made it possible to plot the dependence of the temperature, at which the maximum entropy of mixing was reached on the boiling point (Fig. 3).

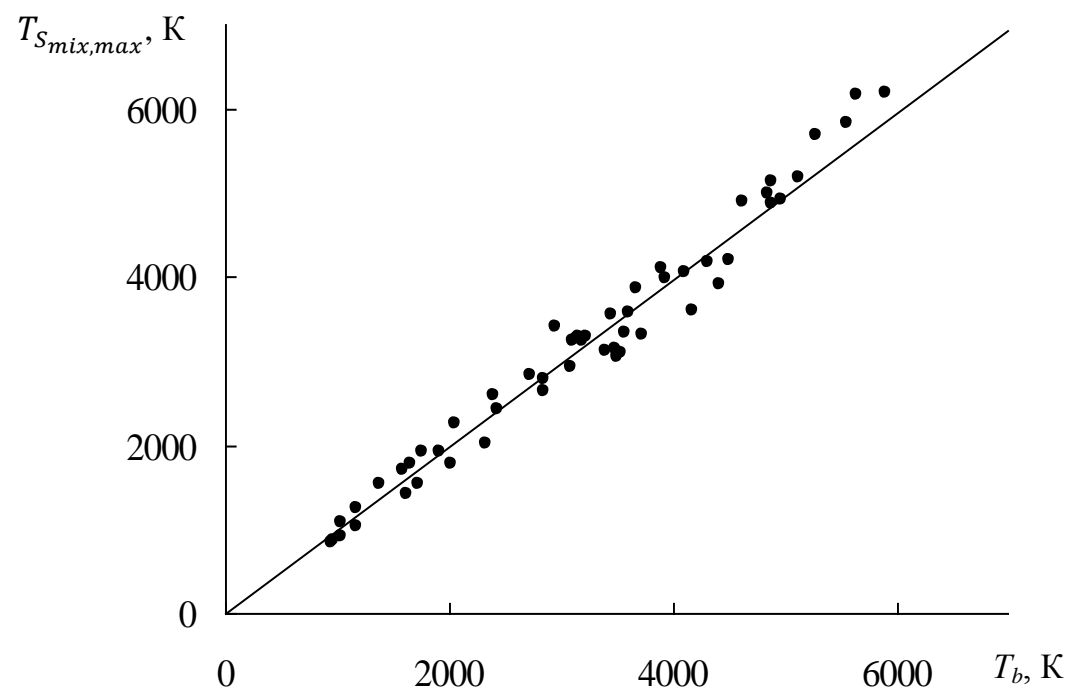

$T_{S_{\text {mix } \text { max }}}$ is temperature of the maximum entropy of mixing, $T_{b}$ is boiling temperature.

Points - calculation according to reference data [12] through $T_{m}$ and $T_{b}$ according to (24), straight line - according to the dependence

Figure 3. Dependence of the temperature of the maximum entropy of randomized particles mixing on the metals boiling point

In this case, a straight-line dependence was obtained, starting from the origin of coordinates:

$$
T_{S_{\text {mix } \text { max }}}=0.9947 T_{b},
$$

indicative of the functional nature of this dependence. It is retained when supplemented with reference data for other simple substances. However, considering the dependence of the boiling point on atmospheric pressure, the resulting invariant applies only to terrestrial conditions, although this limitation is of extremely great evolutionary significance.

Indeed, in this case, the maximum entropy for the joint presence and mixing of crystal-mobile, liquid, and vapor-mobile particles creates unique conditions for the realization likelihood of the widest variety of heterogeneous processes occurring on the Earth's surface, primarily with the participation of volcanic processes with the eruption of liquid lava, geysers, dust and gas clouds both on the land surface and into the atmosphere as well as into the oceans depths. Isn't it this ideal chaotization of solid, liquid, and gaseous states of matter and their mutual penetration into each other in the form of three energy classes of chaotic particles due to the extremely small probability of self-organization of life on Earth?

\section{Conclusions}

As a "zero approximation" for the solid, liquid, and gaseous states of matter as a whole, it is proposed to use a unified Boltzmann distribution over the kinetic energy of chaotic (thermal) particle motion with the allocation of three energy classes, specifically crystal-mobile with thermal energy no higher than $R T_{m}$; liquidmobile with energies above $R T_{m}$, but below $R T_{b}$; vapor-mobile with an energy of at least $R T_{b}$. The sum of the shares of these particles in all combinations at any temperature is equal to unity.

The ratio of the shares of $\mathrm{crm}$-, lqm and $\mathrm{vm}$-particles determines the originality of each state of matter and their relationship as a whole, which can be regarded as a generalization of the previously known scat- 
tered "zero approximations". At the same time, it is possible to carry out not only a qualitative, but also a quantitative analysis of states with a priority basic effect of a randomized component of a substance.

Such an analysis revealed certain invariants of states, independent of the specific type of substance and consistent with the physicochemical properties. So, at $T=0$, the substance is provided only by crystal-mobile particles, which corresponds to the concept of an ideal crystal, and at $T \rightarrow \infty$, only vapor-mobile particles remain, and this is consistent with the concept of an ideal gas. At melting points $T_{m}$ and boiling points $T_{b}$, the shares of particles responsible for the structural stability of the states, respectively, solid and condensed, are close to the golden ratio. Differential analysis of the temperature dependence of the share of crystal-mobile particles established an inflection point equal to $0.5 T_{m}$ and corresponding to the optimal temperature of plastic deformation of Bochvar-Tamman, as well as the range of plasticity effects manifestation (0.3-0.8) $T_{m}$, analytically determined on the basis of the same dependence. The temperature dependence of the share of liquidmobile particles analytically reveals a maximum in the range of the liquid state, which indicates the complexity of this state under the influence of the opposite effect of the dependence for crystal-mobile and vapor-mobile particles [13].

The entropy of mixing of all three energy classes of chaotic particles is characterized by a maximum in the area of the substances boiling point, which indicates a unique variety of possibilities for the implementation of the most complex heterogeneous processes under terrestrial conditions at atmospheric pressure, which ultimately ensured the self-organization of life.

This invariant is illustrated, like all of the above, using barium as an example. The relationship between the maximum entropy of mixing of $\mathrm{crm}$-, lqm- and $\mathrm{vm}$-particles with the boiling point is established for simple substances and is highly adequate.

\section{References}

1 Еланский Г.Н. Строение и свойства металлических расплавов: учеб. пос. для вузов / Г.Н. Еланский, Д.Г. Еланский. - М.: Юрайт, 2020. - 212 с.

2 Леонтович М.А. Введение в термодинамику. Статистическая физика / М.А. Леонтович. - М.: Высш. шк., 1983. $416 \mathrm{c}$.

3 Малышев В.П. Концепция хаотизированных частиц как основа единого отображения твердого, жидкого и газообразного состояний вещества / В.П. Малышев, А.М. Нурмагамбетова (Макашева) // Вестн. Казах. нац ун-та. Сер. хим. — 2004. — № 3(35). - С. 53-67.

4 Сороко Э.М. Структурная гармония систем / Э.М. Сороко. - Минск: Наука и техніка, 1984. — 246 с.

5 Малышев В.П. Вероятностно-детерминированное отображение / В.П. Малышев. - Алматы: Ғылым, 1994. - 376 с.

6 Хоникомб Р. Пластическая деформация металлов; пер. с англ. / Р. Хоникомб. — М.: Мир, 1972. — 389 с.

7 Малышев В.П. Плавкость и пластичность металлов / В.П. Малышев, Б.Т. Абдрахманов, А.М. Нурмагамбетова. М.: Научный мир, 2004. - 148 с.

8 Хартли Р. Передача информации. Теория информации и ее приложения / Р. Хартли. — М.: ИЛ, 1959. — С. 5-35.

9 Maslov V.P., Maslova T.V. Unbounded Probability Theory and Its Applications // Theory of Probability and Its Applications. — 2013. — Vol. 57, No. 3. — P. 444-467. https://doi.org/10.1137/S0040585X97986084.

10 Mahdy M. Weighted Entropy Measure: A New Measure of Information with its Properties in Reliability Theory and Stochastic Orders // Journal of Statistical Theory and Applications. - 2018. - Vol. 17, No. 4. - P. 703-718. https://doi.org/10.2991/jsta.2018.17.4.11.

11 Волков А.И. Большой химический справочник / А.И. Волков, И.М. Жарский. - Минск: Современная школа, 2005. $-608 \mathrm{c}$.

12 Malyshev V.P. Viscosity, fluidity and density of substances. Aspect of Chaotization / V.P. Malyshev, A.M. Makasheva, N.S. Bekturganov. — Lambert Academic Publishing (Germany), 2013. - 340 p.

13 Malyshev V.P. Relationship between the cluster theory of liquids and the Frenkel-Andrade viscosity model / V.P. Malyshev, A.M. Makasheva // Russian Chemical Bulletin. — 2020. — № 69. — P. 1296-1305. https://doi.org/10.1007/s11172-020-2901-9. 


\author{
В.П. Малышев, А.М. Мақашева, Л.А. Бекбаева
}

\title{
Заттың қатты, сұйық және газ тәрізді күйіндегі кристалл қозғалатын, сұйық қозғалатын және бу қозғалатын ретсіз бөлшектердің арақатынасының инварианттары
}

\begin{abstract}
Мақала авторлары Больцман бөлшектерінің хаотикалық қозғалысының кинетикалық энергиясы бойынша таралуына негізделген ретсіз бөлшектер тұжырымдамасын жасаған. Бұл бөлу заттың қатты, сұйық және газ тәрізді күйлерін кристалл қозғалатын, сұйық және бу қозғалатын деп аталатын энергия бөлшектерімен біріктіруге мүмкіндік береді. Мұндай ретсіз бөлшектердің үлестерінің қатынасы заттың белгілі бір агрегаттық күйін анықтайды. Кез келген температурада барлық комбинациялардағы осы бөлшектердің үлестерінің қосындысы бірге тең. Зерттеулер заттың хаотикалық құрамының басым негізгі әсерімен күйлерге сапалы және сандық талдау жүргізуге болатындығын көрсетті. Заттың белгілі бір түріне тәуелсіз және физика-химиялық қасиеттеріне сәйкес келетін күйлердің белгілі бір заңдылықтары табылды. Қарапайым заттар үшін хаотикалық бөлшектердің барлық үш энергетикалық класының жылжу энтропиясы есептелді. Ол заттардың қайнау температурасы аймағында максимуммен сипатталады. Бұл мүмкіндік атмосфералық қысым кезінде жер жағдайындағы ең күрделі гетерогенді процестерді жүзеге асыру үшін мүмкіндіктердің ерекше әртүрлілігін көрсеткен, нәтижесінде осы мүмкіндіктермен өздігінен ұйымдастырылатын өмірді қамтамасыз етеді.
\end{abstract}

Кілm сөздер: Больцманның таралуы, кинетикалық энергия, ретсіз бөлшектер, энтропия, нөлдік жақындау, барий, балку температурасы, қайнау температурасы.

\author{
В.П. Малышев, А.М. Макашева, Л.А. Бекбаева
}

\section{Инварианты соотношений кристаллоподвижных, жидкоподвижных и пароподвижных хаотизированных частиц в твердом, жидком и газообразном состояниях вещества}

\begin{abstract}
Авторами статьи разработана концепция хаотизированных частиц, основанная на распределении Больцмана по кинетической энергии хаотического движения частиц. Данное распределение позволяет объединить твердое, жидкое и газообразное состояния вещества с помощью энергетических частиц, названных кристаллоподвижными, жидкоподвижными и пароподвижными. Соотношение долей таких хаотизированных частиц определяет агрегатное состояние вещества. Сумма долей этих частиц во всех сочетаниях при любой температуре равна единице. Исследования показали, что можно проводить качественный и количественный анализ состояний с приоритетным базовым влиянием хаотизированной составляющей вещества. Были обнаружены определенные закономерности состояний, независимые от конкретного вида вещества и согласующиеся с физико-химическими свойствами. Кроме того, авторами рассчитана энтропия смешения всех трех энергетических классов хаотизированных частиц для простых веществ. Она характеризуется максимумом в области точки кипения веществ. Эта особенность свидетельствует об уникальном разнообразии возможностей для реализации сложнейших гетерогенных процессов в земных условиях при атмосферном давлении, которыми, в конечном итоге, обеспечилась самоорганизация жизни.
\end{abstract}

Ключевые слова: распределение Больцмана, кинетическая энергия, хаотизированные частицы, энтропия, нулевое приближение, барий, температура плавления, температура кипения.

\section{References}

1 Elansky, G.N., \& Elansky, D.G. (2020). Stroenie i svoistva metallicheskikh rasplavov [The Structure and Properties of Metal Melts]. Moscow: Yurait [in Russian].

2 Leontovich, M.A. (1983). Vvedenie v termodinamiku. Statisticheskaia fizika [Introduction to Thermodynamics. Statistical Physics]. Moscow: Vysshaia shkola [in Russian].

3 Malyshev, V.P., \& Nurmagambetova (Makasheva), A.M. (2004). Kontseptsiia khaotizirovannykh chastits kak osnova edinogo otobrazheniia tverdogo, zhidkogo i gazoobraznogo sostoianii veshchestva [The concept of chaotic particles as the basis for a single representation of the solid, liquid and gaseous states of matter]. Vestnik Kazakhskogo natsionalnogo universiteta - Bulletin of the $\mathrm{KazNU}, 3(35), 53-67$ [in Russian].

4 Soroko, E.M. (1984). Strukturnaia garmoniia sistem [Structural harmony of systems]. Minsk: Nauka i tekhnika [in Russian].

5 Malyshev, V.P. (1994). Veroiatnostno-determinirovannoe otobrazhenie [Probabilistic-deterministic mapping]. Almaty: Gylym [in Russian]. 
6 Honicomb, R. (1972). Plasticheskaia deformatsiia metallov [Plastic deformation of metals]. Moscow: Mir [in Russian].

7 Malyshev, V.P., Abdrakhmanov, B.T., \& Nurmagambetova, A.M. (2004). Plavkost i plastichnost metallov [Fusibility and ductility of metals]. Moscow: Nauchnyi mir [in Russian].

8 Hartley, R. (1959). Peredacha informatsii. Teoriia informatsii i ee prilozheniia [Transfer of information. Information theory and its applications]. Moscow: Inostrannaia literatura [in Russian].

9 Maslov, V.P., \& Maslova, T.V. (2013). Unbounded Probability Theory and Its Applications. Theory of Probability and Its Applications, 57, 3, 444-467. https://doi.org/10.1137/S0040585X97986084.

10 Mahdy, M. (2018). Weighted Entropy Measure: A New Measure of Information with its Properties in Reliability Theory and Stochastic Orders. Journal of Statistical Theory and Applications, 17, 4, 703-718. https://doi.org/10.2991/jsta.2018.17.4.11.

11 Volkov, A.I., \& Zharsky, I.M. (2005). Bolshoi khimicheskii spravochnik [Big chemical reference book]. Minsk: Sovremennaia shkola [in Russian].

12 Malyshev, V.P., Makasheva, A.M., \& Bekturganov, N.S. (2013). Viscosity, fluidity and density of substances. Aspect of Chaotization. Lambert Academic Publishing (Germany).

13 Malyshev, V.P., \& Makasheva, A.M. (2020). Relationship between the cluster theory of liquids and the Frenkel-Andrade viscosity model. Russian Chemical Bulletin, 69, 7, 1296-1305. https://doi.org/10.1007/s11172-020-2901-9.

\section{Information about authors}

Malyshev Vitalyi Pavlovich - Doctor of Technical Sciences, Professor, Chief Researcher, Abishev Chemical-Metallurgical Institute, Ermekov street, 63, 100009, Karaganda, Kazakhstan; e-mail: eia_hmi@mail.ru; https://orcid.org/0000-0002-3996-1533;

Makasheva Astra Mundukovna (corresponding author) - Doctor of Technical Sciences, Professor, Karaganda Technical University, Karaganda, Nazarbaev av., 56, 100027, Kazakhstan; e-mail: astra_mun@mail.ru; https://orcid.org/0000-0003-2249-3435;

Bekbayeva Lazzat Akylbaikyzy - Doctoral student, Karaganda Technical University, Karaganda, Nazarbaev av., 56, 100027, Kazakhstan; e-mail: lyazzat.bekbaeva@mail.ru; https://orcid.org/0000-00032543-6380. 